\title{
„Opisanie dni miesięcznych” z chamaiłu Aleksandrowicza
}

DOI: http://dx.doi.org/10.12775/LC.2016.020

Streszczenie. Artykuł obejmuje transkrypcję i edycję fragmentu chamaiłu Aleksandrowicza (rękopis tatarski z XIX w.) zatytułowanego „Opisanie dni miesięcznych”. Fragment ten stanowi odrębną całość, dotyczącą wierzeń Tatarów polsko-litewskich, związanych z poszczególnymi dniami miesiąca, obejmujących wydarzenia z historii świętej islamu, jakie nastąpiły w poszczególnych dniach, oraz prognostyki z nimi związane. Tekst jest publikowany po raz pierwszy, bezpośrednio z rękopisu znajdującego się w zbiorach biblioteki Wydziału Orientalistycznego Uniwersytetu Warszawskiego.

Słowa kluczowe: rękopis tatarski, chamaił Aleksandrowicza, transkrypcja

Abstract. The article includes a transcription and an edition of a fragment of the khamail of Aleksandrowicz (Tatar manuscript of the nineteenth century) entitled "Description of the Month's Days". This fragment is a separate unit, describing beliefs of the Polish-Lithuanian Tatars that are related to particular days of the month, including the events of sacred history of Islam, which occurred each day and prognosis associated with them. The text is published for the first time, directly from the manuscript stored in the collections of the University of Warsaw Faculty of Oriental Studies.

Keywords: Tatar manuscript, khamail of Aleksandrowicz, transcription

\footnotetext{
* Marek M. Dziekan - profesor doktor habilitowany, arabista i islamista, twórca i kierownik Katedry Bliskiego Wschodu i Północnej Afryki na Uniwersytecie Łódzkim. Zajmuje się dziejami i współczesnością cywilizacji arabsko-muzułmańskiej, w tym literaturą, religią, antropologią kulturową i myślą polityczną. Redaktor naczelny „Rocznika Orientalistycznego”, prezes Polskiego Towarzystwa Orientalistycznego. E-mail: mmdziekan@interia.pl.
} 
adania nad piśmiennictwem Tatarów polsko-litewskich w ostatnich latach nabrały tempa. To niezwykle istotny dla polskiej humanistyki nurt studiów, pozostający na granicach kilku dziedzin - orientalistyki, slawistyki, religioznawstwa, kulturoznawstwa, żeby wymienić tylko te najważniejsze. Badania nad twórczością Tatarów koncentrują się przede wszystkim na dwóch jego gatunkach - kitabach, będących zbiorami poważnych tekstów religijnych i prawnych oraz tefsirach - dosł. „komentarzach”, traktowanych jako przekłady Koranu. Mniejszym powodzeniem cieszą się - popularniejsze z kolei, jak się zdaje, wśród samych Tatarów, chamaity (od arab. hamala - „nosić”; hama'il - „coś do noszenia”, dalej: „amulet”). Chamaiły, których rozmaite egzemplarze znacznie różnią się pod względem treści, zawierają teksty modlitw, opisy obrzędów muzułmańskich, legendy o postaciach z dziejów islamu, horoskopy i inne teksty prognostyczne, kwadraty magiczne, zaklęcia i formuły znachorskie, czasem także porady dotyczące np. prowadzenia gospodarstwa wiejskiego. Chamaiły, tworzące niewielkiego rozmiaru książki, służyły prostym muzułmanom, ale przede wszystkim ludziom religii (motła, motna) oraz tatarskim znachorom (fałdżej, siufkacz). Próby wprowadzenia podziału chamaiłów na osobiste, mollińskie (przeznaczone dla mułłów) i fałdżejskie okazały się nietrafione, ponieważ prawie wszystkie znane egzemplarze zawierają jednocześnie teksty służące rozmaitym odbiorcom, mają więc charakter mieszany ${ }^{1}$. Wszystkie pozostają wyraźnie na granicy sakrum i profanum, islamu oficjalnego i ludowego. Tak jest właśnie w przypadku chamaiłu Aleksandrowicza, którego treść została dokładniej omówiona w innym miejscu².

Tekst, który jest osią prezentowanego opracowania, pochodzi z tzw. chamaitu Aleksandrowicza. Zabytek powstał pod koniec XIX w., a zebrany i zapisany został przez Aleksandra Aleksandrowicza z Osmołowa koło Nieświeża. Właścicielami chamaitu byli prawdopodobnie kolejno: Dawid Jasiński i Stanisław Szachno-Romanowicz (1900-1973)3. Po II wojnie światowej chamait przechowywała żona tego ostatniego, która w 1957 r. przywiozła go do Wielkiej Brytanii. Po śmierci właściciela rękopis znajdował się u jego córki, Barbary Hirsz. W 1997 r. kobieta podarowała chamait Zakładowi (teraz - Katedrze) Arabistyki i Islamistyki Uniwersytetu Warszawskiego. Obecnie jest przechowywany w Bibliotece Wydziału Orientalistycznego UW.

Zabytek ten jest stopniowo opracowywany. Jako pierwszy zajął się nim Stanisław Szachno-Romanowicz ${ }^{4}$, od kilku lat nad tekstem pracuje piszący te słowa, publikując rozmaite jego fragmenty ${ }^{5}$. W Uniwersytecie Warszawskim powstała praca magisterska Mariusza

\footnotetext{
1 Szerszą charakterystykę chamaiłów por. np. A. Drozd, Chamaił Sobolewskiego, „Rocznik Tatarów Polskich” 1993, t. I, s. 48-62; idem, Piśmiennictwo Tatarów polsko-litewskich (XVI-XX w.). Zarys problematyki, [w:] A. Drozd, M. M. Dziekan, T. Majda, Piśmiennictwo i muhiry Tatarów polsko-litewskich, Warszawa 2000, s. 13-14.

2 M. M. Dziekan, Chamaił Aleksandrowicza , ,Rocznik Tatarów Polskich” 1998, t. IV, s. 27-30.

3 Szachno-Romanowicz Stanisław, [w:] M. M. Dziekan, Polacy a świat arabski, „Rocznik Tatarów Polskich”, Gdańsk 1998, s. 86-87.

4 S. Szachno-Romanowicz, Planetne dualary Tatarów polskich (tatarskie teksty magiczno-ochronne w chamaile Aleksandrowicza), „Rocznik Tatarów Polskich" 1997, t. IV, s. 7-25.

${ }_{5}$ M. M. Dziekan: Chamaił Aleksandrowicza, s. 30-43 - tam także faksymile wybranych stron rękopisu; Einige Bemerkungen über die islamische Literatur der polnisch-litauischen Tataren, [w:] Studies in Arabic and Islam, red. S. Leder et al., Leuven-Paris-Sterling, Va 2002, s. 185-191; Czas święty i czas świecki w chamaile Aleksandrowicza: godziny i dni niechsiowe, [w:] Orientas Lietuvos Didžiosios Kunigaikštijos Visuomenès Tradicijoje: Totoriai ir Karaimai / Orient in the Social Tradition of the Grand Duchy of Lithuania: Tatars and Karaims / Orient w tradycji społeczeństwa
} 
Nowotczyńskiego napisana pod moim kierunkiem na temat tego chamaitu ${ }^{6}$, a wybrane aspekty językowe opracowała w swej pracy magisterskiej obronionej na uniwersytecie we Fryburgu Bryzgowijskim Insa Klemme ${ }^{7}$.

Podobnie jak w poprzednich publikacjach na temat tego zabytku, nie stosuję ani dla tekstu polskiego zapisu fonetycznego, ani dla słów arabskich - transkrypcji naukowej, lecz jedynie uproszczoną. Celem edycji nie jest bowiem analiza lingwistyczna tekstu, lecz religioznawczo-kulturoznawcza zawartości zabytku. Transkrypcja naukowa i/lub zapis arabski są stosowane tylko w przypisach lub komentarzach w przypadku miejsc wymagających szczegółowych wyjaśnień. Podział na zdania oraz zastosowanie znaków interpunkcyjnych stanowią element mojej interpretacji tekstu. W nawiasach kwadratowych zaznaczono numery stron rękopisu.

$$
*
$$

[s. 6] Opisanie dni miesięcznych

1. Pierwszego dnia miesiąca Pan Bóg stworzył pierwszego człowieka Adama ${ }^{8}$. Ten dzień bardzo dobry prośbę zanosić, ślub brać, wesele sprawować, w drogę jechać, kupić, przedać, nowe odzienie kroić, szyć i obnawiać. Jednym słowem na wszystko dobry, tylko jeśli kto zachoruje, a we dwa dni zdrowy nie będzie, to cały miesiąc chorować, potem wyzdrowieje. Takoż jeśli tego dnia dziecko się narodzi, nauczone dobrych obyczajów, długowieczne i bogate będzie. A jeśli tej nocy sen zaśnisz, rokuje na dobro, a jeśli co zginie, to się znajdzie.

2. Drugiego dnia miesiąca Pan Bóg Ewę ${ }^{9}$, żonę dla Adama stworzył. Ten dzień też dobry. W drogę jechać, kupić, przedać, nowe odzienie kroić, szyć i obnawiać, ślub brać, wesele sprawować dobrze. Tylko jeśli kto w ten dzień zachoruje, a za cztery dni nie wyzdrowieje, to pod śmiertelnym strachem będzie. A jeśli tej nocy sen zaśnisz, rokuje niedobrze. A jeśli dziecko się narodzi, uparte, krnąbrne i rodzicom przeciwne i nieposłuszne będzie. A jeśli co zginie lub kto co ukradnie, to się znajdzie.

Wielkiego Księstwa Litewskiego: Tatarzy і Karaimi / Ориент в общественной традиции Великого княжества Литовского: татары и караимы, red. T. Bairašauskaitè, G. Miškinienė; H. Kobeckaitè, Vilnius 2008, s. 81-89; Chcąc znać i wiedzieć, jak ciągną́ fał alkuranowy w "Chamaile Aleksandrowicza", [w:] Tatarzy Wielkiego Księstwa Litewskiego w historii, języku i kulturze, red. J. Kulwicka-Kamińska, Cz. Łapicz, Toruń 2013, s. 125-133; Кахuн? Шаман? Колдун? Как стать фалджеем по хамаилу Александровича, [w:] Tiurku istorija ir kultūra Lietuvoje / Turks' History and Culture in Lithuania / История и культура тюрков в Литве, red. T. Bairašauskaite, G. Miškinienè, Vilnius 2014, s. 214-226.

6 M. Nowotczyński, Tatarzy polsko-litewscy. Wybrane zagadnienia kultury duchowej na podstawie Chamaiłu Aleksandrowicza, niepublikowana praca magisterska, Instytut Orientalistyczny Uniwersytetu Warszawskiego, Warszawa 2004.

7 I. J. Klemme, Der Chamail Aleksandrowicz. Die sprachwissenschaftliche Analyse einer Handschrift der polnischlitauischen Tataren aus dem 19. Jahrhundert, niepublikowana praca magisterska, Albert-Ludwig-Universität, Freiburg im Breisgau 2011. Por. M. M. Dziekan, Praca magisterska o Tatarach polsko-litewskich na uniwersytecie we Fryburgu Bryzgowijskim (Niemcy), „,Przegląd Tatarski” 2011, nr 4, s. 17.

8 Zapis w chamaile: ادد" آدم : Informacje tego typu podaję tylko w tych miejscach, gdzie zapis chamaiłu różni się od poprawnego zapisu w piśmie arabskim.

9 W tekście zastosowano formę „Ewa” (zapis: "او), nie zaś często spotykaną w piśmiennictwie tatarskim formę Chawa/Hawa (od arab. Hawwa). 
3. Trzeciego dnia miesiąca Pan Bóg Adama i Ewę z raju wyprawił i lud proroka wniwecz obróci ${ }^{10}$. Ten dzień na wszystko niedobry.

[s. 7] 4. Czwartego dnia miesiąca Habil ${ }^{11}$ się narodził. Ten dzień na wszystko co dobry. Prośbę czynić, listy, prośby do ważnych osób pisać, posyłać, ślub brać, wesele sprawować, nowe odzienie kroić, szyć i obnawiać dobrze. Tylko w drogę jechać nie wolno. A jeśli tego dnia zachoruje i w dziesięć dni do zdrowia nie przyjdzie, to długo chorować będzie, strachem wielkim będzie, jednak do zdrowia przyjdzie. Lekarstwo przyjmować dobrze. A jeśli dziecko się narodzi, rozumne, pojętne, nauczone i bogobojne, posłuszne i długowieczne będzie.

5. Piątego dnia miesiąca Kabil ${ }^{12}$ się narodzil i tego dnia swego brata Habila zabił i w ten dzień na jego Pana Boga przekleństwo zesłano. Ten dzień na wszelkie dzieła niedobry, wystrzegać się należy. Jeśli w ten dzień kto zachoruje i w pięciu dniach nie wyzdrowieje, to pod śmiertelnym strachem będzie. A jeśli dziecko się narodzi, głupie i krótkiego wieku i wszelkich niecnot będzie. Takoż tajemne rzeczy objawią się. Jeśli co zginie lub kto co ukradnie, nie szukaj, nie znajdziesz.

6. Szóstego dnia miesiąca na wszystko co ten dzień dobry. Orać, bronować, zboża siać, sady sadzić, studnie, doły, jamy kopać, w drogę do wojska jechać, nowe odzienie kroić, szyć i obnawiać, w swaty posyłać, zaręczyny robić, ślub brać, wesele sprawiać dobrze. A jeśli dziecko się narodzi, obyczajne, przykładne, szczęśliwe, nauczone, bogobojne i rodzicom posłuszne będzie i wszystko, na co by nie spojrzał, robić będzie. Jednym słowem do wszystkiego będzie miał ochotę, zdolność i pojęcie. Kto w ten dzień zachoruje, [s. 8] a nie będzie zdrowy pierwszego albo szóstego dnia, to cały miesiąc chorować będzie i potem zdrowy będzie. A jeśli sen zaśnisz, we dwa dni objawi się. A jeśli co zginie lub kto co ukradnie, to się znajdzie.

7. Siódmy dzień na wszystko niedobry. A jeśli dziecko się narodzi, bogate, lecz krótkiego wieku będzie. A jeśli kto w ten dzień zachoruje, długo chorować i pod śmiertelnym strachem będzie. Jeśli tego dnia przyszło gusie ${ }^{13}$ brać, to należy ciepłą wodą. A jeśli sen zaśnisz, we dwa dni objawi się. A jeśli co zginie lub kto co ukradnie, nie szukaj, nie znajdzie się.

8. Ósmy dzień na wszystko dobry. W ten dzień prorok Salih ${ }^{14}$ rodził się. W drogę jechać, prośbę czynić, w swaty posyłać, ślub brać, wesele sprawować, odzienie kroić, szyć i obnawiać, kupować, przedawać, orać, bronować, siać, sady zasadzać, jednym słowem na wszystko dobrze. A jeśli tego dnia zachoruje, to dziesięć dni chorować będzie i po dziesięciu dniach zdrowy będzie. A jeśli dziecko się narodzi, dobrych obyczajów i do wielkich

10 Stwierdzenie niejasne. Nie jest pewne, czy chodzi o to, że Bóg obrócił wniwecz lud jakiegoś proroka, czy też że lud obrócił wniwecz swojego proroka. Bardziej prawdopodobna jest ta pierwsza wersja, nie wiadomo jednak, o który lud i którego proroka chodzi. W Koranie są opowieści o czterech prorokach, których ludy zostały przez Boga zatracone - to ludy proroków: Saliha (por. niżej), Nuha, Huda, Luta (Lota) i Szu'ajba.

11 Biblijny Abel, postać niewspominana z imienia w Koranie - do niego i jego brata odnosi się sura 5, wersety 27-31. Opowieść o Habilu i Kabilu por. J. Danecki, Opowieści Koranu, Warszawa 1991, s. 122-123; M. M. Dziekan, Symbolika arabsko-muzułmańska, Warszawa 1997, s. 13; G. Vajda, Hābill wa Käbīl, [w:] The Encyclopaedia of Islam CD_ROM Edition v.1.1, Leiden 2001.

12 Biblijny Kain.

13 Od arab. ghusl „duże ablucje”, przybierające w praktyce formę kąpieli. Tu: po prostu kąpiel. Zapis w chamaile: غوثل, poprawny zapis arabski: غسل.

14 Jeden z koranicznych proroków wysłanych do arabskiego ludu Samud, postać kilkakrotnie wspominana w Koranie, np. 11, 61-63; 7, 74-78 i inne. Ponieważ Samudyci nie posłuchali prorockiego wezwania do monoteizmu, zostali przez Boga unicestwieni. Por. A. Rippin, Sälih, [w:] The Encyclopaedia of Islam CD_ROMEdition v.1.1. Zapis w chamaile: صاليح, poprawny zapis arabski: صالح. 
dostojeństw dojdzie. A jeśli sen zaśnisz, to bardzo dobry ma być. A jeśli czeladnik uciekł, to powróci. A co zgubione albo ukradzione, to się znajdzie.

9. Dziewiąty dzień na wszystko dobry. Zboże lub co innego siać, sad zasadzać, do panów iść, w drogę jechać, do wojennej służby iść, przedawać, kupować, w swaty posyłać, ślub brać, wesele sprawować, odzienie kroić, szyć, w poselstwo posyłać. Jeśli co [s. 9] zaśnisz, rychło objawi się. Jeśli co zginie, to się znajdzie.

10. Dziesiąty dzień dobry. $\mathrm{Nuh}^{15}$ prorok narodził się. W swaty posyłać, ślub brać, wesele sprawować, odzienie kroić, szyć i obnawiać, orać, bronować, siać i tak dalej. A jeśli zachoruje, do osiemnastu dni zdrowy będzie. A jeśli dziecko się narodzi, szczęśliwe, bogobojne i obyczajne będzie. A jeśli sen zaśnisz, w dwudziestu dniach objawi się i ma być pomyślny. A jeśli co posłyszysz, nowina pomyślna. A jeśli tego dnia wzięto do więzienia, rychło będzie uwolnionym. Tego dnia głowę myć dobrze. A jeśli czeladnik uciecze, to powróci, albo co zginęło, to się znajdzie.

11. Jedenasty dzień dobry. Tego dnia Szyt ${ }^{16}$ prorok się narodził. Jednym słowem powodzi się na wszystko, co dobre. Dzień pisma posyłać, prośby zanosić do Pana Boga, urzędników i cesarzów. W drogę jechać, przedawać, kupować, sług najmować, odzienie kroić, szyć i obnawiać, orać, bronować, siać, sady sadzić, studnie, jamy, kanały kopać, w swaty posyłać, zaręczyny, ślub, wesele sprawować dobrze. A jeśli dziecko się narodzi, to ozionie ${ }^{17}$. A jeśli kto tego dnia zachoruje, prędko wyzdrowieje. Sen zaśnisz, będzie nie zły ani dobry i w dziesięciu dniach objawi się. A co przepadnie lub ukradną, to się znajdzie.

12. Dwunasty dzień też dobry. Bajtu al-Mukadisi ${ }^{18}$ zaczęty tego dnia budować. Na wszystko co dobry dzień. Kupować, przedawać, odzienie kroić, szyć i obnawiać, w swaty posyłać, ślub brać, wesele sprawować bardzo dobrze. [s. 10] A jeśli kto w ten dzień zachoruje, ciężko chorować będzie, lecz wyzdrowieje. A jeśli sen zaśnisz, dobry będzie. A jeśli sługa uciecze, to powróci, a co zginie lub ukradną, to się znajdzie. Tego dnia należy akindej-

\footnotetext{
15 Biblijny Noe, w islamie jeden z proroków; opowieść o nim jest zawarta w Koranie w surze 71 zatytułowanej jego imieniem. Por. J. Danecki, op. cit., s. 126-131; M. Gaudefroy-Demombynes, Narodziny islamu, Warszawa 1988, s. 269-271; B. Heller, Nūh, [w:] The Encyclopaedia of Islam CD_ROM Edition v.1.1.

16 Arab. Szis, biblijny Set, trzeci syn Adama, niewspominany w Koranie, w islamie jeden z proroków. Por. Cl. Huart, C. E. Bosworth, Shith, [w:] The Encyclopaedia of Islam CD_ROM Edition v.1.1. Zapis w chamaile: شط, poprawny zapis arabski: شيث.

17 Odczytanie niepewne - w chamaile zapis: اوُطونَنَ lub اؤَنَ Co do pierwszej możliwości lektury: „utonie" - wątpliwości budzi fakt, że dzień ten jest opisany ogólnie jako dobry. Czasownik „ozionąć" uwzględnia tzw. Słownik Wileński (Słownik języka polskiego, Wilno 1861, s. 950; wersja elektroniczna na stronie http://eswil.ijp-pan.krakow.pl/, data dostępu: 20 IV 2015): "Ozionąć, v. nieuż. Ozinąć, ął, ozionie, v. ozieje, [...] 1) kogo; tchem obwiać, otchnąć. fig. Wenus z Djanq oddechem swym słodkim te miejsca ozionęły. Schnq lilje i róże, cokolwiek ozieje Zarażone powietrze, umiera i mdleje. 2) = wzrokiem; oczarować. Wilk go ozionął. Powiadajq, że wilk piérwszém swojem widzeniem człowieka ozionie, że czasem i ratunku głosem wołać nie może. Wilczaczku, ozionąłé owieczkę niebogę. Ona za toba bieży, choć ma w sercu trwogę. 3) = fig. co; chciwe oko na co rzucić, chciwie żądać. Aleksander Wielki świat wszystek myślą ozionął". W chamaile być może w znaczeniu „wiele osiągnie, będzie bogaty”. Por. także Elektroniczny słownik języka polskiego XVII i XVIII w., http://xvii-wiek.ijp-pan.krakow.pl/pan, hasło "ozionąć" (data dostępu: 20 IV 2015), gdzie cytat z Pamiętników Paska, przysłowie „Co wilk ozionie, to go nie minie”. Por. także Słownik polszczyzny XVI wieku, t. 22, Wrocław 1994, s. 438; S. B. Linde, Słownik języka polskiego. Tom trzeci M-O, Lwów 1857 (reprint: Gutenberg-Print, Warszawa 1994), s. 637. Podobnie jak w przypadku "utonięcia” mało prawdopodobne wydaje się użycie tego słowa w znaczeniu „rzucić urok" - por. D. Kowalewska, Magia i astrologia w literaturze polskiego oświecenia, Toruń 2009, s. 239. Za pomoc w analizie tego leksemu dziękuję Pani dr hab. Joannie Kulwickiej-Kamińskiej (UMK, Toruń).

18 Arab. Bajt al-Mukaddas, czyli Jerozolima. Zapis w chamaile: بيتو الموقادث, poprawny zapis arabski: بيت المقدس.
} 
ną ${ }^{19}$ porą cztery rekiaty ${ }^{20}$ namaz modlić się, a ukończywszy taką, sześć pokłonów siedżde ${ }^{21}$ uczyń i czego tylko będziesz u Pana Boga prosił, to Pan Bóg prośbę wysłucha i uskuteczni. A jeśli dziecko się narodzi, bogobojne i obyczajne będzie. W ten dzień dobrze gusiel brać i głowę myć.

13. Trzynasty dzień na wszystko niedobry. Tego dnia Faraon ${ }^{22}$ przeklęty rodził się. To jeśli tego dnia dziecko się narodzi, wielkich niecnot i krótkiego wieku będzie. Jeśli żyć będzie to muniafik ${ }^{23}$, przeciwnik i niewiernik boski. A jeżeli w ten dzień kto zachoruje, to pod strachem śmiertelnym będzie, jednak wyzdrowieje. A jeśli sen zaśni, to złe i dobre rzeczy usłyszy. Jeśli co zginie i pilnie będzie szukał, to znajdzie.

14. Czternasty dzień na wszystko dobry. Kupować, przedawać, odzienie kroić, szyć i obnawiać, w swaty posyłać, ślub brać, wesele sprawiać, w drogę jechać, orać, bronować, siać, sady sadzić, studnie, jamy, doły kopać i bardzo wiele innych robót robić. Tylko niedobrze krew puszczać, lekarstwo przyjmować. A jeśli dziecko się narodzi, bogobojne, długowieczne i dobrych obyczajów będzie. A jeśli tego dnia zachoruje i rychło nie wyzdrowieje, to za dwadzieścia i sześć dni zdrowy będzie. A jeśli sen zaśnisz, takoż w dwadzieścia sześć dni objawi się. A co posłyszysz, to kłamstwo. A co [s. 11] zginie, to się znajdzie.

15. Piętnastego dnia przeklęty Nemrod Ibrahima proroka w ogień rzucal ${ }^{24}$. Tego dnia siedemdziesiąt i dwa języki zesłane na złe i na dobre rzeczy ${ }^{25}$, więc ten dzień na dobre rzeczy dobrze, a na złe źle. Jako to domy, meczety budować, w drogę jechać, krew puszczać, lekarstwo przyjmować, dzieci do nauki oddawać, kupić, przedać, na to dobrze. Jeśli dziecko się narodzi, szczęśliwe, lecz dobrej wymowy mieć nie będzie. A jeśli zachoruje, długo chorować będzie. Jeśli sen zaśnisz nie dobry, nie zły, to $\mathrm{w}$ kuszluk ${ }^{26}$ godziny dwa rekiaty nemaz pomódl się, Pan Bóg prośbę przyjmie. A jeśli co posłyszysz, to kłamstwo. Jeśli co zginie, to się nie znajdzie.

16. Szesnasty dzień bardzo dobry. Konie, bydło, zboża i inne rzeczy kupować, przedawać, kupować ${ }^{27}$, orać, siać, bronować, sady zasadzać, doły, jamy, kanały i studnie kopać. Do łaźni iść, krew puszczać, lekarstwa przyjmować, w swaty wysyłać, ślub brać, wesele sprawować, paznokcie raznąć, włosy strzyc, golić, w drogę wyjeżdżać. Na wszystko, co dobrze. A jeśli dziecko się narodzi, dobrych obyczajów będzie. A jeśli kto zachoruje, a w pięciu dniach zdrowy nie będzie, to pod strachem wielkim będzie.

19 Akindejny od tur. ikinde - wieczór; rekiat - od arab. raka - cykl pokłonów modlitewnych.

20 Zapis w chamaile: ركعت, poprawny zapis arabski: ركعة.

21 Od arab. sadżda - pokłon modlitewny z dotknięciem czołem ziemi; nemaz - tur. namaz, modlitwa (arab. salat). Zapis w chamaile: ناماظ, poprawny zapis w piśmie arabskim: نماز.

${ }^{22} \mathrm{~W}$ Koranie określenie to $\mathrm{w}$ formie Firaun funkcjonuje jako imię własne, stąd zapisuję je wielką literą. Kilkadziesiąt razy wspominany w Koranie, np. 7, 103-141; 40, 24-46; symbol tyrana przypisującego sobie cechy boskie. Por. J. Danecki, op. cit., s. 171-181; A. J. Wensinck, G. Vajda, Fir 'awn, [w:] The Encyclopaedia of Islam CD_ROM Edition v.1.1. Zapis w chamaile: فار "اون, poprawny zapis arabski: فر عون.

${ }^{23}$ Arab. munafik: „obłudnik, hipokryta”; określenie występujące w Koranie, będące także tytułem sury 63. Zapis w chamaile: مونيافيق (tutaj z „krótkim alifem” po literze ja, w dniu 21. zgodnie z zapisem arabskim), w poprawnej ortografii arabskiej: منافن.

24 Imię Nemroda (arab. Nimrud) nie jest wspominane bezpośrednio w tekście Koranu, ale komentatorzy wiążą go z dwoma fragmentami dotyczącymi lbrahima: sura 2, werset 258 i sura 21 , werset 68 . Wątek o rozkazie spalenia Ibrahima pojawia się w tym drugim miejscu. Por. J. Danecki, op. cit., s. 131-140.

${ }_{25}$ Chodzi o biblijną opowieść o wieży Babel. Nawiązaniem do niej może być wzmianka w Koranie, sura 28 werset 38. Tradycja muzułmańska nie zna jednak „pomieszania języków”, jest to więc wyraźna interpolacja o pochodzeniu chrześcijańskim.

26 Kuszłuk, z tur. kușluk, przedpołudnie.

27 Powtórka w oryginale. 
17. Siedemnasty dzień na wszystko co dobry, tylko w swaty posyłać, ślub brać i wesele sprawować niedobrze.

18. Osiemnasty dzień też bardzo dobry na wszystko co. W ten dzień Izaak ${ }^{28}$ prorok się narodził. Jednym słowem na wszystko co dobry, nawet jeśli w ten dzień kto zachorował, to prędko wyzdrowieje. A jeśli sen zaśni, w pięciu dniach objawi się.

[s. 12] 19. Dziewiętnasty dzień dobry. Tego dnia Jakub ${ }^{29}$ prorok narodził się. Na wszystko co dobry, tylko budować i odzienie kroić, szyć i obnawiać niedobrze.

20. Dwudziesty dzień dobry. $\mathrm{W}$ ten dzień Ejjub ${ }^{30}$ prorok rodził się. I w ten dzień Ibrahim $^{31}$ prorok Nemroda przeklętego wniwecz obrócił. Tego dnia prośbę czynić do Pana Boga i wielkich panów. Przyjętą i uskutecznioną będzie. Jednym słowem na wszystko dobry, tylko niedobrze lekarstwa przyjmować i krew puszczać. A jeśli dziecko się narodzi, głuche będzie. A jeśli tego dnia zachoruje, wielkie męki zadzieją, lecz wyzdrowieje. A jeśli sen zaśni, rychło się objawi. A jeśli parobek lub jaka inna sługa uciecze, to nie wrócą. A jeśli co posłyszysz, to się sprawdzi.

21. Dwudziesty pierwszy dzień bardzo dobry. Prośbę czynić, odzienie kroić, szyć i obnawiać, takoż w drogę jechać, krew puszczać, lekarstwa przyjmować. Tylko niedobrze wiele nie do rzeczy mówić. A jeśli dziecko narodzi się, niewierny, muniafikiem będzie i niech się strzeże różnych przygód. A jeśli pomyślną nowinę posłyszy, to się sprawdzi.

22. Dwudziesty drugi dzień bardzo dobry. $W$ ten dzień Jusuf ${ }^{32}$ prorok narodził się. Na wszelką rzecz dobrze, tylko jeśli dziecko się narodzi, to za dziecięcych lat swoich wielkich trudności zadzieje. Potem do wielkiej sławy dojdzie. A jeśli sen zaśni, to prędko się objawi.

23. Dwudziesty trzeci dzień na złe rzeczy niedobry. Tego dnia Nuh prorok się narodził i tego dnia ludom jego zginienie [s. 13] przyszło $^{33}$. Pan Bóg rozkazał, aby w ten dzień strzegli się od złych rzeczy i fałszu, by nie przysięgali. A jeśli w ten dzień kto zachoruje, prędko wyzdrowieje. A jeśli dziecko się narodzi, to łotr i złodziej będzie. A jeśli dobrą nowinę posłyszy, to się sprawdzi.

24. Dwudziesty czwarty dzień na wszystko co niedobry. Tego dnia wystrzegać się należy.

25. Dwudziesty piąty dzień takoż na wszystko co niedobry. Na początek wystrzegać się należy.

\footnotetext{
28 Arab. Ishak; zapis w chamaile: ايصاءق, poprawny zapis arabski: اسحاق.

29 Biblijny patriarcha, w islamie prorok, wspominany wiele razy w Koranie, np. 2, 132-136; 3, 84; 4, 163. Por. R. Firestone, Ya ' $k u ̄ b$, [w:] The Encyclopaedia of Islam CD_ROM Edition v.1.1.

${ }^{30}$ Arab. Ajjub, biblijny Hiob, w islamie prorok, kilkakrotnie wspomniany w Koranie, np. 4, 163; 21, 83. Por. M. Gaudefroy-Demombynes, op. cit., s. 300; A. Jeffery, Ayyūb, [w:] The Encyclopaedia of Islam CD_ROM Edition v.1.1.

31 Biblijny Abraham, w islamie jeden z najważniejszych proroków, wielokrotnie wspominany w Koranie, jego imieniem jest zatytułowana sura 14. Por. J. Danecki, op. cit., s. 131-147; M. M. Dziekan, Symbolika arabskomuzułmańska, s. 14; R. Paret, Ibrähïm, [w:] The Encyclopaedia of Islam CD_ROM Edition v.1.1; M. GaudefroyDemombynes, op. cit., s. 271-278.

32 Józef egipski, w islamie jeden z proroków; opowieść o nim jest zawarta w surze 12 zatytułowanej jego imieniem. Por. J. Danecki, op. cit., s. 154-171; M. Gaudefroy-Demombynes, op. cit., s. 296-298; R. Firestone, Yūsuf, [w:] The Encyclopaedia of Islam CD_ROM Edition v.1.1. Zapis w chamaile: يوسوف, poprawny zapis arabski: يوسف.

${ }_{33}$ Chodzi o unicestwienie "ludu Lota" (Koran, 7, 80-83) - koraniczny odpowiednik biblijnego zniszczenia Sodomy i Gomory.
} 
26. Dwudziesty szósty dzień nadzwyczaj dobry na wszystko, co. W ten dzień Musia ${ }^{34}$ prorok rodził się. W ten dzień Pan Bóg egipskiego króla Faraona przeklętego i ludzi jego wniwecz obrócił. Jednym słowem na wszystko co dobry.

27. Dwudziesty siódmy dzień dobry na wszystko co. Czeladź najmować, bydło i inne rzeczy kupować, lekarstwo przyjmować, odzienie kroić, szyć i obnawiać, włosy strzyc, golić, do łaźni iść, krew puszczać, w swaty posyłać, ślub brać. A jeśli sen zaśnisz, będzie dobry. Takoż co posłyszysz, tegoż dnia objawi się. A jeśli dziecko się narodzi dobrych obyczajów, bogobojne, przykładne, szczęśliwe i nauczone będzie.

28. Dwudziesty ósmy dzień takoż na wszystko dobry.

29. Dwudziesty dziewiąty dzień dobry. Musia prorok na Synaj górę tego dnia wstąpił z rozkazu Pana Boga i z Panem Bogiem rozmawiał i czterdzieści dni [s. 14] był na niej i Pan Bóg mu dał święty zakon dla Izraelitów, więc ten dzień na wszystko co dobry bez wyjątku.

30. Trzydziesty dzień nadzwyczaj dobry na wszystko co, bo w ten dzień proroka Jakuba syn się narodził Sama'un ${ }^{35}$.

Podstawowym celem horoskopu jest wskazanie pomyślnych i niepomyślnych dni w miesiącu. A zatem mamy szesnaście dni pomyślnych (2., 6., 8., 9., 10., 11., 12., 16., 18., 22., 26., 27. , 28., 29., 30.), sześć dni jednoznacznie niepomyślnych (3., 5., 7., 13., 24., 25.) i osiem ambiwalentnych (4., 14., 15., 17., 19., 20., 21., 13.), czasem trudnych nawet do takiej kwalifikacji (dzień 15. i 23.). A zatem w większości przypadków mamy do czynienia z dniami dobrymi.

Pomyślność dni jest związana w największym stopniu z wydarzeniami z historii świętej islamu, które tradycja wiąże z tymi dniami. Szczególnie chodzi o wydarzenia z życia proroków - głównie o dni ich narodzin lub ważnych momentów w ich życiu. Pojawiają się tu postaci znane zarówno z dziejów świętych chrześcijaństwa i judaizmu (Adam, Ewa, Mojżesz, Abraham), jak i znane wyłącznie z tradycji muzułmańskiej (Salih). Połączenie narodzin Adama z pierwszym dniem miesiąca wydaje się nawiązaniem do faktu, że był on pierwszym człowiekiem. Ale przecież w muzułmańskich mitach stworzenia to nie człowiek był pierwszym stworzeniem Boga, logiczniejsze więc wydawałoby się powiązanie tego faktu z szóstym dniem miesiąca. Powiązanie tych wydarzeń z konkretnymi postaciami jest najwyraźniej produktem wyłącznie islamu ludowego, nie udało mi się bowiem znaleźć informacji na ten temat w najważniejszych i najpopularniejszych „Opowieściach o prorokach” (arab. Kisas al-anbija) - ani w zbiorze Al-Kisai'ego ${ }^{36}$, ani Ibn Kasira ${ }^{37}$. Choć pojawiają się w tych dziełach informacje dotyczące narodzin rozmaitych proroków, to ograniczają się do przekazów związanych z wiekiem ich ojców i są mierzone w dziesiątkach lub nawet setkach lat, a nie $\mathrm{w}$ dniach. Brak tego typu informacji także w dwóch dostępnych mi edycjach kitabów -

34 Arab. Musa, biblijny Mojżesz, jeden z najważniejszych proroków islamu, wielokrotnie wspominany w Koranie. Por. J. Danecki, op. cit., s. 171-186; M. Gaudefroy-Demombynes, op. cit., s. 278-290; D. B. Macdonald, Mūsā, [w:] The Encyclopaedia of Islam CD_ROM Edition v.1.1.

35 Arab. Simun, Siman - biblijny Symeon (Szymon), syn patriarchy Jakuba.

36 Muhammad Ibn Abd Allah al-Kisa'i, Kisas al-anbija, wyd. I. Eisenberg, Leiden 1922.

37 Abu al-Fida Ibn Kasir, Kisas al-anbija, Bajrut 1982. 
Milkamanowicza $^{38}$ i Łuckiewicza ${ }^{39}$. Biorąc pod uwagę charakter tekstu i obecność zapożyczeń z tradycji judeochrześcijańskiej (przekaz o pomieszaniu języków), należy przypuszczać, że może chodzić o jakieś przekazy chrześcijańskie - na takie jednak również się nie natknąłem. W dodatku tak ważny dla chrześcijan 25. dzień (grudnia) jest w analizowanym horoskopie jednym z najgorszych dni w miesiącu.

Wróżby uwzględniane w „Opisaniu” mają dość ograniczony treściowo charakter, $\mathrm{w}$ wielu przypadkach mamy do czynienia $\mathrm{z}$ dosłownym ich powielaniem. Odnoszą się do codziennych zajęć odbiorców, mieszkańców wsi - a zatem pracy w polu, zwierząt domowych, podróży i chorób. Istotną rolę odgrywa kwestia snów - jest więc ten tekst także częściowo rodzajem specyficznego sennika, nieco podobnego do tego zamieszczonego na s. 27-29 rękopisu ${ }^{40}$. Tutaj jednak najważniejsze jest to, czy sen się spełni, czy nie, nie zaś, jak tam - sam fakt, czy coś się śniło, czy nie. Podobnie jednak, jak w tamtym, nie stanowi on interpretacji konkretnych marzeń sennych i w ten sposób odbiega od senników znanych $\mathrm{z}$ tradycji europejskiej ${ }^{41}$. Ważny, stały element to także troski związane z życiem rodzinnym - narodziny dzieci i ich los, swaty, śluby i wesela. Nie ma natomiast żadnej wzmianki o śmierci i pogrzebach.

W chamaile Aleksandrowicza znajdujemy jeszcze inne teksty o charakterze prognostycznym, odnoszące się do kolejnych dni miesiąca. Taki charakter mają dni „niechsiowe” (s. 37-38 rękopisu ${ }^{42}$ ) oraz wspomniany sennik. Porównanie wszystkich tekstów wskazuje na wyraźne niekonsekwencje. Należy jednak pamiętać, że chamaiły były zazwyczaj kompilowane z rozmaitych źródeł, stąd takie niezgodności wydają się naturalne, jeśli dotyczą spraw zdecydowanie bliższych wierzeniom ludowym niż dogmatom religijnym. Jedna wyraźna niekonsekwencja pojawia się zresztą także w „Opisaniu dni miesięcznych”. Prorok Nuh miał się urodzić jednocześnie 10. i 23. dnia miesiąca! To świadczy w jeszcze dosadniejszy sposób o kompilacyjnym charakterze nie tylko chamaitu jako całości, ale nawet poszczególnych jego rozdziałów mających tworzyć zwartą całostkę. Kompilacyjny charakter tekstu można także dostrzec w gramatycznej niejednolitości poszczególnych fragmentów. W drugim dniu miesiąca mamy np. najpierw formę bezosobową: „W drogę jechać, kupić, przedać [...] dobrze”, a następnie w drugiej osobie: „A jeśli tej nocy sen zaśnisz, rokuje niedobrze”. Co ciekawe, niejednolitość ta nie ma stałego charakteru i tego samego typu treści w rozmaitych miejscach przyjmują różne formy gramatyczne, np. trzynastego dnia wróżba na temat snu występuje w trzeciej osobie: „A jeśli sen zaśni, to złe i dobre rzeczy usłyszy”. Czasem tego typu niezgodności pojawiają się w jednym zdaniu, jak w dniu dziewiątym: „A jeśli tego dnia wzięto do więzienia, rychło będzie uwolnionym”. Wśród cech charakterystycznych stylistyki „Opisania” uwagę zwraca użycie zwrotu „wszystko co” zamiast „wszystko” / „cokolwiek”

${ }^{38}$ H. Jankowski, Cz. Łapicz, Klucz do raju. Księga Tatarów litewsko-polskich z XVIII wieku w przekładzie ..., Warszawa 2000.

39 G. Miškinienè, Ivano Laucevičiaus kitabas, Vilnius 2009.

40 Oprac. zob. M. M. Dziekan, Chamaił Aleksandrowicza, s. 33-35.

41 Stanisława Niebrzegowska wskazuje na konstytutywne elementy sennika jako gatunku. Są to: obraz, wykładnia i rama gatunkowa. W senniku tatarskim brak pierwszego elementu konstytutywnego, czyli obrazu sennego, który następnie byłby poddawany interpretacji. Ten element zastępuje w tym przypadku sam fakt widzenia sennego, który jest interpretowany. Jak pisze wspomniana autorka, ,jeśli tekst sennika traci jeden ze składników podstawowych, traci też status właściwy tekstom tegoż gatunku" (S. Niebrzegowska, Polski sennik ludowy, Lublin 1996, s. 26). Stosując ściśle tę zasadę, należałoby stwierdzić, że takie tatarskie senniki nie są sennikami.

42 Por. szczegółowo: M. M. Dziekan, Czas święty i czas świecki. 
w stwierdzeniach „dobry na wszystko co” (por. dni: 4., 6., 12., 17., 18., 19., 24., 25., 26., 27., 29., 30.).

„Opisanie dni miesięcznych” stanowi, jak wspomniałem na początku, edycję kolejnego fragmentu chamaiłu Aleksandrowicza, jeszcze szerzej prezentując treść tego interesującego zabytku. Dokumentuje on nie tylko wierzenia wywodzące się z islamu jako takiego, ale ukazuje także dalsze przejawy synkretyzmu wierzeń polskich muzułmanów pochodzenia tatarskiego.

\section{Bibliografia}

Danecki Janusz, Opowieści Koranu, Warszawa: Nasza Księgarnia, 1991.

Drozd Andrzej, Chamaił Sobolewskiego, „Rocznik Tatarów Polskich” 1993, t. I.

Drozd Andrzej, Piśmiennictwo Tatarów polsko-litewskich (XVI-XX w.). Zarys problematyki, [w:] Andrzej Drozd, Marek M. Dziekan, Tadeusz Majda, Piśmiennictwo i muhiry Tatarów polsko-litewskich, Warszawa: Res Publica Multiethnica, 2000.

Dziekan Marek M., Chamaił Aleksandrowicza, „Rocznik Tatarów Polskich” 1998, t. IV.

Dziekan Marek M., Chcac znać i wiedzieć, jak ciagnać fat alkuranowy w „Chamaile Aleksandrowicza”, [w:] Tatarzy Wielkiego Księstwa Litewskiego w historii, języku i kulturze, red. J. KulwickaKamińska, Cz. Łapicz, Toruń: Towarzystwo Naukowe w Toruniu, 2013.

Dziekan Marek M., Czas święty i czas świecki w chamaile Aleksandrowicza: godziny i dni niechsiowe, [w:] Orientas Lietuvos Didžiosios Kunigaikštijos Visuomenès Tradicijoje: Totoriai ir Karaimai / Orient in the Social Tradition of the Grand Duchy of Lithuania: Tatars and Karaims / Orient w tradycji spoteczeństwa Wielkiego Księstwa Litewskiego: Tatarzy i Karaimi / Ориент в общественной традищии Великого княжества Аитовского: татары и караимы, red. T. Bairašauskaitè, G. Miškinienè; H. Kobeckaitè Vilnius: Vilniaus Universiteto Leidykla, 2008.

Dziekan Marek M., Einige Bemerkungen über die islamische Literatur der polnisch-litauischen Tataren, [w: Studies in Arabic and Islam, red. S. Leder et al., Leuven-Paris-Sterling, Va: Uitgeverij Peeters, 2002.

Dziekan Marek M., Praca magisterska o Tatarach polsko-litewskich na uniwersytecie we Fryburgu Bryzgowijskim (Niemcy), „Przegląd Tatarski” 2011, nr 4.

Dziekan Marek M., Szachno-Romanowicz Stanistaw, [hasło w:] idem, Polacy a świat arabski, Gdańsk: Niezależne Wydawnictwo „Rocznik Tatarów Polskich”, 1998.

Dziekan Marek M., Кахин? Шаман? Колдун? Как стать фалджеем по хамаилу Александровича, [w: Tiurku istorija ir kultūra Lietuvoje / Turks' History and Culture in Lithuania / История и культура тюрков в Аитве, red. T. Bairašauskaite, G. Miškinienè, Vilnius: Vilniaus Universiteto Leidykla, 2014.

Dziekan Marek M., Symbolika arabsko-muzutmańska, Warszawa: Verbinum, 1997.

Elektroniczny stownik języka polskiego XVII i XVIII w., http://xvii-wiek.ijp-pan.krakow.pl/pan, hasło „ozionąć”.

Firestone R., Ya 'kūb, [hasło w:] The Encyclopaedia of Islam CD_ROM Edition v.1.1, Leiden: Brill, 2001.

Firestone R., Yüsuf, [hasło w: ] The Encyclopaedia of Islam CD_ROMEdition v.1.1, Leiden: Brill, 2001. Gaudefroy-Demombynes Maurice, Narodziny islamu, Warszawa: PIW, 1988.

Heller Bernard, Nūh, [hasło w:] The Encyclopaedia of Islam CD_ROM Edition v.1.1, Leiden: Brill, 2001. 
Huart Claude, Clifford E. Bosworth, Shïth, [hasło w:] The Encyclopaedia of Islam CD_ROM Edition v.1.1., Leiden: Brill, 2001.

Ibn Kasir Abu al-Fida, Kisas al-anbija, wyd. Abd al-Kadir Ahmad Rida, Bajrut: Al-Maktaba al-Islamijja, 1982.

Jankowski Henryk, Czesław Łapicz, Klucz do raju. Księga Tatarów litewsko-polskich z XVIII wieku w przekładzie ..., Warszawa: Dialog, 2000.

Jeffery A., Ayyūb, [hasło w:] The Encyclopaedia of Islam CD_ROM Edition v.1.1, Leiden: Brill, 2001.

Al-Kisa’i Muhammad Ibn Abd Allah, Kisas al-anbija, wyd. I. Eisenberg, Leiden: Brill, 1922.

Klemme Insa J., Der Chamail Aleksandrowicz. Die sprachwissenschaftliche Analyse einer Handschrift der polnisch-litauischen Tataren aus dem 19. Jahrhundert, Freiburg im Breisgau: Albert-LudwigUniversität, 2011 [maszynopis pracy magisterskiej].

Kowalewska Danuta, Magia $i$ astrologia w literaturze polskiego oświecenia, Toruń: Wydawnictwo Naukowe UMK, 2009.

Linde Samuel B., Stownik języka polskiego. Tom trzeci M-O, Lwów 1857, reprint: Warszawa: Gutenberg-Print, 1994.

Macdonald Duncan B., Mūsā, [hasło w:] The Encyclopaedia of Islam CD_ROM Edition v.1.1, Leiden: Brill, 2001.

Miškinienè Galina, Ivano Luckevičiaus kitabas. Lietuvos totorių kultūros paminklas, Vilnius: Lietuvių kalbos institutas, 2009.

Niebrzegowska Stanisława, Polski sennik ludowy, Lublin: Wydawnictwo UMCS, 1996.

Nowotczyński Mariusz, Tatarzy polsko-litewscy. Wybrane zagadnienia kultury duchowej na podstawie Chamaitu Aleksandrowicza, Warszawa: Instytut Orientalistyczny Uniwersytetu Warszawskiego, 2004 [maszynopis pracy magisterskiej].

Paret Rudi, Ibrāhim, [hasło w: The Encyclopaedia of Islam CD_ROM Edition v.1.1, Leiden: Brill, 2001.

Rippin Andrew, Șäliḥ, [hasło w:] The Encyclopaedia of Islam CD_ROM Edition v.1.1, Leiden: Brill, 2001.

Stownik polszczyzny XVI wieku, t. 22, Wrocław: Ossolineum, 1994.

Stownik Wileński (Stownik języka polskiego), Wilno 1861, wersja elektroniczna na stronie http:// eswil.ijp-pan.krakow.pl/.

Szachno-Romanowicz Stanisław, Planetne dualary Tatarów polskich (tatarskie teksty magiczno-ochronne w chamaile Aleksandrowicza), „Rocznik Tatarów Polskich” 1997, t. IV.

Vajda Georges, Hābill wa Käbïl, [hasło w: ] The Encyclopaedia of Islam CD_ROM Edition v.1.1, Leiden: Brill, 2001.

Wensinck Arent J., Georges Vajda, Fir' awn, [hasło w: The Encyclopaedia of Islam CD_ROM Edition v.1.1, Leiden: Brill, 2001. 